\title{
Argument for method: An application of Barthes' language codes in poetry
}

\begin{abstract}
This essay is a direct application of the five language codes described in Roland Barthes' essay "Style and its image". The language codes consist of the Actional (Proairetic) code; the literal action of subjects or characters within the dramatic plot of the poetry; the Referential, or the cultural worldview of the work's subject or theme; the Semantic, those suggestive details which describe characters or the setting of the work; the Hermeneutic, considering language units which conceal unknown aspects of the work or facts about character, setting or other qualities of the writing, though also those qualities traditionally considered literary conventions; and the Symbolic, or those aspects of language which suggest ideas beyond the literal text itself. The writer takes a fresh look at an earlier example of Contemporary American poetry using Structuralist discourse as a tool with which to explicate Donald Hall's poem "The Town of Hill", first published in 1975.
\end{abstract}

Keywords: critical theory, literary studies, comparative literature, interdisciplinary studies, post-structuralist theory.

\section{Argument for method}

In Roland Barthes Jonathan Culler states that the eminent literary theorist was fascinated by ideas to such an extent that each "...time Barthes urged the merits of some new, ambitious project-a science of literature, a semiology, a science of contemporary myths, a narratology, a history of literary signification, a science of divisions, a typology of textual pleasure-he swiftly passed into something else" (Culler 1983: 12). Posthumously, others have resumed Barthes' interests with great enthusiasm and vigor. His theories were taken up in linguistics, comparative literature, culture studies and many other academic disciplines. They were also applied to film study of such American classics as The Wizard of $\mathrm{Oz}$. However, my interest here remains with the language codes Barthes describes in "Style and Its Image" (The Rustle of Language, Barthes 1989). To the best of my knowledge there exist very few applications of the language codes in the study of poetry. Existing studies tend toward semiotics, stylistics, rhetorical analysis or Jakobson's linguistic analysis of poetry (Culler 1976). Where studies of the language are found, they usually only 
focus on narrative. Structuralist poetics typically take a semiotic approach rather than an objective analysis described in "The Structuralist Activity” (Critical Essays, Barthes 1972). Regardless of the fact of the Post-Structuralist condition of literary history, these ideas can still find a meaningful application to the study of poetry. Barthes said that just “... as Einsteinian science compels us to include within the object studied the relativity of reference points, so combined action of ..." [any synthesis of reading approaches] “...compels us in literature, to relativize the relations of scriptor, reader and observer (critic)" (Barthes 1972: 57). Thus, there exist in any discourse a set of given parameters, though they are relative to each other and not fixed. Therefore, scholars could examine works in slightly different ways and remain within a developed theoretical framework. However, also because certain limits will appear in the application of such an approach which have been affected by the development of other critical disciplines, I have used the term "stereographic discourse" because this is the descriptive term used by the originator of the code system himself. Also, historically, since all postmodernity shares this condition of knowledge, the approach I use and the way I discuss certain aspects will seem more appropriate than others. Since there exists no single model and only a given set of generalized concepts, what this means is that any critical method can be combined and utilized with any other discourse. This position sounds like an advocation of the multi-disciplinary zeitgeist of our age, although I believe such an endeavor is rewarding for those interested in the application of theoretical ideas to the study of literature. I believe in a balanced, close reading approach while also employing synchronous and diachronous modes of discourse. Reading strategies are no simpler today as a choice between merely two options. At this point in literary history we have seen good examples as to how to approach literary ideas as well as bad ones.

What would be the best argument for an application of this theoretical discourse if one were to make a claim of validity for Barthes' language codes in this age? Structuralism being "post-"today, is obviously a time condition, being historically after Structuralism, and a method of discourse many feel was obliterated by Deconstructionist literary theory. One could call the discourse PostStructuralist because this term is historically attributed to a few scholars whose ideas theoretically assumed a status of popular attention shortly after Structuralist discourse was translated for publication in the United States, roughly beginning in 1960 and culminated just after 1970 (Leitch 1988: 238-266). The fact that Barthes' language codes were never applied to poetry validates my attempt, though in considering such an application of these ideas some modification of approach is necessary. As Dr. Calum Gardner suggested to me in a recent communication, many see "...the five codes as a limit case demonstrating what Structuralism can and can't achieve and where it needs to become 'post"' (personal communication, 2018). He also warned that perhaps a text of jouissance would be a most difficult challenge. Further, he said that “...most poems aren't narrative...the codes are specifically designed for narrative texts. I think you'd need to adapt the five codes for poetic language in particular-you would need to replace or redefine the proairetic and hermeneutic codes..." (personal communication). I agree with the above concerns and have 
taken them into consideration at various places in the following essay. I will mention these aspects where they become relevant in the reading of "The Town of Hill".

Since Barthes' language codes describe how aspects of language operate within the work of art to the effects and traits we attribute to literature, I feel to title the approach a Stereographic analysis of poetry seems appropriate. This type of literary analysis would have a different approach in comparison with pure Linguistics, Semiotics or even the Structuralist discourse of narratives Barthes illustrates in his $S / Z$ (1975). Concern arises in the application of the language codes in one's treatment of two types of poetry; formal and free-verse. Formalist poetry already illustrating a high degree of structure, would seem most logically the better material because the extent to which the rules of combination govern its form are pervasive. Free-verse, by its own nature seems devoid of them or at least exhibits fewer formal attributes. The structural analysis of formal poetry yields a most robust material for formal commentary because form in this sense is what it is because the rules which govern form make the work a structure more specific beyond language. In this sense there are essentially two layers of language we notice right away, the formal aspects and then what the poem communicates. In the explication of free-verse, the codes must be exploited to such a degree that one must ascertain what the writer is doing with material in the given literary context and then move from the rules of combination that can be detected to a discussion of the work as a literary work of art. At the level of close reading, I consider the symbolic (SYM) code as most relevant because this level also illustrates a layer exhibiting the rules of combination. As Perloff (2004) illustrates in her discussion of Language poets in Differentials, close reading is still valuable because it first identifies common elements among writers and can then be used for comparative analysis. I briefly outline my understanding of the five codes and their usage at the end of this introduction. Some may call this reading approach a discourse of Barthean stylistics or a misunderstanding of the extent of the language codes themselves. In the application of my argument I have mapped the process of understanding how the codes operate in a single American text which I hope illustrates a new validity. This is not Semio-Linguistics, Semiotics or even the Linguistic Structuralism of Roman Jakobson. The most well-known, historical example of what this approach is not remains best illustrated in Michael Riffaterre's essay, "Describing Poetic Structures: Two Approaches to Baudelaire's 'Les Chats"' (1970: 188-230). The layered-ness, the free-play and the pleasure of the text are enough for valid applications of the critical Stereographic approach to the study of poetry.

One could logically ask if it is possible to say what I have said without reference to the language codes of Roland Barthes? Perhaps, but such a negative response limits and omits discussion of certain aspects of what was originally a Structuralist approach. As we know historically, other reading approaches developed in response to the need to address these aspects of language. This document serves to establish relevance in the justification of a literary analysis, a discourse that many abandoned, at least in its application to the study of poetry. Today we see many examples from contemporary scholars applying the codes to narrative or other areas of culture studies. Authors Sabah Zaib and Ghulam Mustafa Mashori (2014) examined the "Five Codes of Barthes 
in Shahraz's Story S“A Pair of Jeans”: a Post-Structural Analysis”. Maria Asumta Reniminryu has written a thesis titled, "Analysis on Roland Barthes Codes in The Wizard of Oz: A Semiotic Approach" (2009). Bayu Dirgasari authored a 2008 study titled: "A Symbolism Analysis as Reflected in John Keats's "Ode to a Nightingale". This retrospective reinvigoration of ideas indicates that literary discourse has moved beyond any single or common critical approach and that the norm of our time is a combination of approaches, a blend of or multiplicity or whatever ideas the scholar feels relevant for the text of consideration. Such an approach would benefit from a close reading applied to a stereography of poetry because the language codes exist for clearly mapping and contextualizing discourse. However, there are moments where aspects of textual analysis seem most appropriate in this regard. Rather than blending two known types into a third species of discourse, this method slows and places attention upon the fabric of text in illustration of its nature, character and inner-workings, how the parts relate to each other, though not as purely functional a definition as this may sound. Scholars who placed moral and ethical emphasis upon Structuralism were mistaken. A text such as Robert Scholes's Structuralism in Literature: An Introduction (1974) distorts in this regard the role and meaning of such an approach. The method of discourse is as Barthes described in "The Structuralist Activity" (Critical Essays, Barthes 1972) - a means of dissection and articulation of the literary object, the text. Rather than destructive, I see this activity as productive and objective free-play. The aspect of being "post-" only implies the questioning of its own ground where limits exist. Merit lies in not creating universals in a discourse which is best treated as a science of the literary object than of didactic modes of meaning. Such discourse maps especially helpful problem in the examination of "difficult" literary works. Also, as with the age, such a contemporary approach would utilize comparative analysis so as to thoroughly ground the argument in various types of literary evidence over time. A single analysis will not validate the application of the code system nor prove its pervasive relevance across genres. However, for preliminary purposes, a single explication established a beginning point for future comparative analysis of the application of the five codes in the study of poetry.

To this end, I also turned to the Roland Barthes essay, "The Structuralist Activity" from the collection Critical Essays (Barthes 1972). My approach is direct: to use the Barthes essays, "The Structuralist Activity" and "Style and Its Image" (The Rustle of Language, Barthes 1989), as the basic framework and concepts for outlining the direct application of the language codes in reading contemporary American poetry. The framework described in the Roland Barthes essay, “The Structuralist Activity" (Critical Essays, Barthes 1972), provides a two-fold method as well as a goal for discourse. Dissection and articulation are the two, central activities which comprise the approach in just this order. In poetry which challenges the conventions of literature, it is expected that the sequence may be employed differently depending on the work in question. Barthes says, "...to dissect the first object...is to find in it certain mobile fragments whose differential situation engenders a certain meaning..." (1972: 216). In free-verse, images serve as fragments of meaning and operate differently compared with, for example, images in formal poetry. My method of dissection for this paper has attempted a discussion of the parts as they relate to the whole. Since 
the "paradigm" is the poem itself, having its structure broken into separate phrases, words, images and syntactical units, articulation exists as the discussion of groups of lines and their significance. Barthes writes that articulation means "Once the units are posited" discourse "...must discover in them or establish for them certain rules of association..." (1972: 17). These rules of combination also ultimately present how the codes operate.

Articulation, for Barthes, exists as the goal of discourse and the means to an end. In discovering the "rules of combination" for the work of art, one relates a significance between signifier and signified, word and language, between thought and experience (1972: 217). Thus, articulation forms the rationale toward meaning in discourse or is discourse forming toward significance, though dissection and articulation together form the whole activity. Barthes writes that

the goal of all structuralist activity, whether reflexive or poetic, is to reconstruct an "object" in such a way as to manifest thereby the rules of functioning, (the "functions") of this object. Structure is therefore actually a simulacrum of the object but a directed, interested simulacrum, since the imitated object makes something appear which remained invisible, or if one prefers, unintelligible in the natural object. (Barthes 1972: 214-215)

Throughout this essay, I attempt to deploy these types of analysis in repeated fashion, often alternately, though in logical sequence. I move through the poem, examining sets of lines and often move back and forth through the work and the codes in the process of discourse.

In the study of poetry, the "rules of combination" among conventions have two essential layers. One could characterize the work in this sense as an archaeology of forms. The two layers consist of the English language itself and the conventions of the literary genre of poetry. Within the literary layer, however, one may notice other aspects, especially the concept of style which most adroitly confronts the reader with numerous qualities of difference. The sonnet remains a classic example. The more highly formalized the poetic work, the easily such "rules of combination" are located. In such cases the rules make them what they are. With the free-verse poem, one would have to examine other "rules of combination" where elements of formality are absent and the grammar of some other speech becomes most prevalent, in order to? decipher "rules of combination", because in these cases one would say that the rules are slightly different or that attention must find another locus. In formal poetry, the rule is the measure. It is the essence of its being. In free-verse one must look for a different tissue of causality, though the rules one finds may still be those operating within formal poetry. Free-verse, in one sense, illustrates a degree of language where most of the poetic aspects have been stripped away or limited to a certain degree. Typically, free-verse illustrates less formal surface rules of textuality. This is the reason why one must look deeper into the text to find the associations that govern its being. In a poem such as Keats's "On First Looking Into Chapman's Homer", the rules of combination are those of the sonnet; a fourteen lined poem written in iambic pentameter, having a rhyme scheme of ABBA ABBA CD CD CD with the standard octave and sestet division, complete with turn and volta. In this way, there exist three 
prevalent sets of rules of combination or association; first, of total line length, second, of metrical pattern and last of rhyme scheme. However, other rules exist; choice of subject or theme, diction and the fact that even though writers understand the rules of form which make the sonnet what it is, there are deviations from patterns that are an accepted norm throughout various historical literary periods. One only need look to other scholars already having discussed such stylistic differences, such as Northrop Frye's (1963) chapter on the Age of Johnson poets in Fables of Identity or Frederick Nims (1985), who has also documented in his essay "The Sestina”, the varied cultural evolution of that form. Even the more contemporaneous Annie Finch (2012) has given us a look at historical examples of such variance with her anthology Villanelles. Considering this, it is true of America today that a subversion of form is the collective, writerly cultural norm. Given also recent anthologies of "hybrid" poetry, regional poets, cultural ethnic poetry or even writers of otherness, we should not find it surprising that so wide and various motives exist in the publishing industry of our time.

Numerous sub-forms of variation govern any formal poem, not just sonnets, villanelles, sestinas, pantoums or the more unfamiliar forms; skinny, dorsimbra or the minute. Aside from these primary forms and rules of combination, there also exist that set of rules and expectations known as literary conventions; rhyme, diction, metaphor, simile, syntax, alliteration, symbol: that whole range of literary hand-book terminology that could apply to any given literary work. It is true that these ideas are more like tools than rules, though they still possess an operating principle through which one learns the correct way to execute their usage. This happens to be another area where rules of combination overlap or are subsumed within other rules of a larger framework. Rules, like the sonnet form itself, have been lifted from the epistemology of genre and culturally normalized as exalted forms - a special form above most others, thus the tradition of higher status in certain societies or literary periods. Even historically, as in Fuller's (1972) study, The Sonnet, a hierarchy has been established as what is most highly valued even though variations of the sonnet have been historically accepted as the norm. This essay examines one poem using the language codes which examine layers of language.

Another aspect this brings to light is the depth of structure and the unique features only code analysis evokes. All literary texts embody the symbolic, or (SYM) code aspect; a greater or generic form of symbolism. This deeper structure, which often provides context for the immediate, literal layer of text, is either an authorial, personal deliberation or a cultural aspect. Barthes says “...this is the place for multivalence and reversibility; the main task is always to demonstrate that this field can be entered from any number of points, thereby making depth and secrecy problematic" (Barthes 1975: 19). Sometimes it is a matter attributed to spirituality or other aspects of the text which determine and shape its symbolic value. My use of free-verse in this regard refers to poetry that is free of verse qualities; metrical feet, highly formal structures and even tendencies of selection of material. If the deeper level of the symbolic code is not evident, then only the generic scripting of text as symbolic of the speech act remains evident. 
The cultural-referential code, (REF), serves as the living historical-cultural context from which the work originates and considers textual, qualitative statements made concerning the material. Barthes writes that "...the cultural codes are references to a science or body of knowledge; in drawing attention to them, we merely indicate the type of knowledge (physical, physiological, medical, psychological, literary, historical, etc." (Barthes 1975: 20). In Robert Frost's "Stopping by Woods on a Snowy Evening", for example, the setting establishes this code as socio-economic. The speaker describes a rural landscape, though what determines the cultural-referential aspect is that focus of attention on environment and the facts we learn as we read about the speaker's observations of someone else's property and his social status in the community. In Percy-Bysshe Shelley's "Ozymandias", the cultural-referential code would concern architectural or religious monuments. In Walt Whitman's sonnet, "When I Heard the Learned Astronomer", the cultural-referential code could be stated as the scientific knowledge of astronomy. It is also important to note that just as Barthes placed each lexia under close scrutiny, such analysis of poetry should also consider individual or pairs of lines, unless otherwise dense, in the identification of the presence of the codes. Obviously, there exists the possibility for multiple citations of the same code within any given poem. One should begin analysis with titles, just as Barthes (1975) did.

If poetry can be discussed in terms of plot, the actional, (ACT), the proairetic concerns any literal actions which take place in the work. This code, though sometimes viewed in the context of an interrelationship among the other codes, remains essentially a structural analysis of the significance of action in relation to the structure of the work as a whole. Anywhere action predominates over narrative, the flow of a structural reading slows to disclose how this influences reading. Note that only plot-driven events constitute the proairetic. For poetry, the actions described will be less centered upon plot as the dramatic aspect of poetry is more centrally tied to the development of the ideas and emotions expressed in the work.

The hermeneutic, (HER), concerns the enigmas of the text that are not explained and therefore demand explication. Barthes describes this as a list of the "...various (formal) terms by which enigma can be distinguished, suggested, formulated, held in suspense, and finally disclosed..." (Barthes 1975: 19). The hermeneutic also refers to the sub-plot or any device meant to add emotional emphasis to a text, though also exhibits moments where the enigma manifests itself through language. It is not that the hermeneutic exists in any permanent, symbiotic relationship with any single code; moreover, it is as if the enigmas of text serve as a way to reveal insight or awareness through literal evocation of multiple codes through defamiliarization in the Russian Formalist sense of the term. This technique serves as a way to slow attention or awareness at particular moments in the text so as to create a breach of thought in the flow of any of the codes. This interruption typically facilitates a questioning or reflection, diversion of thought, subverts thought, or modify an explication toward a complex awareness or an un-foreseen conclusion. Barthes cautions that "...these terms will not always occur..." though "...they will often be repeated; they will not appear in any fixed order" (Barthes 1975: 19). This code would seemingly have greater emphasis in 
discussions of the avantgarde small 'a' and 'g' here: avant-garde literature, Language poetry or any text engaging complex thoughts or human experience.

The semantic, (SEM) code, operates like theme in literary analysis. Barthes states that of these aspects "...we merely indicate them-without, in other words, trying either to link them to a character (or a place or an object) or to arrange them in some order so that they form a single thematic grouping..." (Barthes 1975: 19). I think of the (SEM) or, semantic code as "...a single thematic grouping..." or a literary theme (Barthes 1975: 19). In every example Barthes provides, this is evident. Barthes also writes that the semantic code "...points to...additional meaning by way of connotation," though "...Barthes does not mean a free-association of ideas...but a correlation immanent in the text...an association made by the text-as-subject within its own system..." which he calls "...semantic connotations that have special meaning for the work at hand" (www.perdue. edu/english/theory). This would seem to have the grounding principle of a group of semes which bear the connotation of their form toward a given single impression or quality of character. The description of this character is most central in the exploitation of this code. In the strictest literary sense, the semantic denotes and modifies character and setting.

In the theoretical, stereographic reading approach that I advocate, only the language of the text and its arrangement on the page forms the attention of the critic in the activity of articulation. Sometimes this fails to produce an adequate explication and I draw upon the biography of the writer or his poetics. However, each of the codes are just as pliable and less finite as the one preceding. Instead of singular modes branching out from a single code, there exist instead innumerable modes that remain possible for one's discourse and no single one of them, or no single group of them can be thought of as the only valid course of articulating structure. Perhaps this remains characteristic of all Postmodern texts, though should not be thought of as a limitation. Such multiplicity exists as a positive and not a negative trait. Multiplicity of text in this sense pertains not to the multiple ways text may become interpreted, but the numerous, valid, navigable routes the scholar pursues through discourse because of the stereographic nature of text. The only hindrance in this regard lies in the fact of limited application of the codes to the study of poetry. The following essay is a new attempt in literary scholarship which hopefully maps fruitful possibilities in the application of the codes to the genre of poetry.

The activities in my essay have taken the sequence of first, dissection and then articulation. In poetry which challenges the conventions of literature, it is expected that the sequence may be employed differently depending on the work in question. In "The Town of Hill”, images serve as fragments of meaning and operate differently compared with, for example, formal poetry. My method of dissection for this paper has attempted a discussion of the parts as they relate to the whole. Since the "paradigm" is the poem itself, having its structure broken into separate phrases, words, images and syntactical units, articulation then, exists as the discussion of their internal and relational significance. Barthes writes that articulation means "Once the units are posited" structuralist discourse "must discover in them or establish for them certain rules of association..." (Barthes 1972: 217). I have refrained from discussion of any linguistics, semiotics, or the 
explication of the text which would seem to be the province of another, more intricate discipline, no matter how justified or relevant.

\section{Articulation and dissection: Explication of structuralist stereographic aspects of Donald Hall's "The Town of Hill"}

Donald Hall's poem, “The Town of Hill”, was titled such in reference to a town named Hill, in the history of New Hampshire which was flooded as a preservation project. The title operates in both semantic and cultural-referential codes, first because the title makes reference to the name of a place. Second, knowing the history of the name of the town and how it came to be named such, gives depth of cultural facts which are not disclosed to the reader during a reading of the work. However, the semantic connotation functions more explicitly in poetry as a suggestive device; a literary element which opens readings toward various levels of meaning. If a reader had no knowledge of this cultural-referential fact, that the town once existed and that it was located close to a place where the poet once lived, the poem would not take on the same quality or depth of meaning. "The Town of Hill" plainly states the object of the work-that the subject of the poem is the town itself. We are reading a poem about a town named Hill. Lack of clarity on behalf of the author only contributes to the mystery of its structure and meaning. Hall says:

It was a poem which went back to an earlier style. I don't think it looks much like other poems, but it is a poem that is greatly dependent on, and interested in, its own sound. It is Goatfoot and Milktongue - and probably more Milktongue than Goatfoot and in a way I think that is what it is secretly about. About life before birth even, or perhaps very early on after birth. But I am not sure what it is secretly about, not yet. That usually takes me a few years. I mean, a few years after the poem's finished (in: Turner 1977: 128).

The terms "Goatfoot" and "Milktongue" refer to concepts the author elaborates in a 1973 essay titled, "Goatfoot, Milktongue and Twinbird; The Psychic Origins of Poetic Form". "Goatfoot” in this sense pertains to rhythm of a line of poetry, whereas "Milktongue" refers to the pleasure of words. In "The Town of Hill", the semantic communicates through connotative language from a fixed point in time, literally the historical existence of a town named Hill. Right away there exist cultural connotations of the town: it was named after Isaac Hill, a New Hampshire Democrat, who also served as the state's governor in the early nineteenth century. It is a cultural fact that the town was established in a geographically poor position and thus, had to be flooded to protect other towns in the area. The town was then relocated to another geographic area.

Structurally, the poem has been arranged in twenty-four lines of free-verse, though in the appearance of twelve pairs of enjambed lines. The last line is the only end-stopped unit in the entire poem. I will comment on rhythm at a later point, which yields some interesting effects among line-break and idea. The poem opens as we read, "Back of the dam, under / a flat pad" (lines 1-2). "Back of the dam" is the literal location of the town of Hill, now submerged under 
water. Line two provides a figural, visual image as to what the surface of the water resembles. Line one constitutes a cultural-referential point as a fixed place the reader can imagine as the setting where the action of the poem takes place. In its descriptive sense, "a flat pad" resembles some sort of utilitarian, depersonalized object; a pad of concrete, of glass or some similar, functional object. In front of this is positioned the industrial symbol of progress and capitalism - the dam, which here exists as a symbol of loss and destruction. Thus, the dam operates a primary symbol of industrialism in the beginning of the poem. When the reader reads, "flat pad", there is no realization of what?, as even with background knowledge of the poet and his life, only after several readings was this reader able to grasp what this phrase represents. The phrase, "a flat pad", functions as a hermeneutic in that its description is an enigma of universal language. We do not know until the additional lines are read what we are visualizing. The semantic connotation here hints toward a speaker in sympathy with the former citizens of Hill, who were forced to move in the face of the greater political machinery of legislative funding that created the dam. Thus, thematically, this established the idea of a conflict between technology and humanity.

The next two stanzas clarify the first enigma, though introduce another puzzle. The speaker says, "of water, church / bells ring // in the ears of lilies, / a child's swing" (lines 3-6). Thus, the figurative language of "flat pad // of water" has been explained as the reader should make the connection to the title and realize that the speaker here refers to the submerged town of Hill. As the poem's first, literal actional element, "church / bells ring" (lines 3-4). This signals however, another enigma because we know literally that churches do not exist under water, much less bells ring. The seemingly normal action, common in many small, American townships, then takes on a heightened, imaginative effect as the reader knows they cannot literally be sounding. Bells ring in the personified 'ears of lilies', serving as a further hermeneutic intended to draw the reader's attention to the memory of it's the bells? The lilies? presence and the day-to-day events that would typically occur. Hall says of the poem's subject, “...perhaps it is part of a return to the past, and a re-examination of the past..." (in: Turner 1977: 129). Connotatively, the implications of this action could be more significant. Bells only ring in the New England cultural-referential sense on Sunday, Wednesday evening before prayer service or during special events, such as weddings. The cultural-referential meaning draws the reader's eyes, connotatively, symbolically up to the cupola to contemplate what usually dwells at its peak-the Christian cross atop the spire. What is the reader to make of this gesture? The death knell of the township? Perhaps that it is just the passing of the town being memorialized in the poem. The lilies have been personified, for only their "ears" hear those sounds, though realistically this is only in memory. The lilies could be reference to flowers in a yard, though most likely they serve as a connotative re-grounding in the scene initially described of a body of water where a town once existed. The lilies are most likely the spatterdock on the pond surface common to most Eastern wetlands. This literal image alludes to another symbolic context in which the flowers were commonly grown in yards. Thus, the poem's codes operate in two modes at once; past and present, figural and literal. 
The next two stanzas illustrate scenes from the town that once existed, though also introduce further enigmas. The speaker says, "a child's swing // curls in the current / of a yard, horned // pout sleep / in a green" (lines 6-10). With the dynamic of underwater environments established, enigmas of the hermeneutic here operate in a different way. When the reader reads that "a child's swing // curls in the current / of a yard" we know these are again images of past life which are now submerged in water (lines 6-8). The next turn of phrase which signals a puzzle are the words, "horned // pout", a type of catfish native to the Eastern United States. The image, however, of "horned // pout sleep / in a green // mailbox" remains another image of a reversal of environments (lines 8-11). Elements in the first four images of the poem evoke the setting of small-town America; the "church", the "child's swing" situated in "a yard" as well as the "mailbox". They are all classic images of early, twentieth century American culture, even though the mailbox is green because it is now covered in algae. Thus, the cultural-referential aspect of these lines denotes a time gone to industrial progress. meaning a little unclear Resident Clifford Otto has posted actual photos of the original town of Hill at www.ghosttowns.com which show foundations, pipes and partial sidewalks. When the actual town was moved, the region only experienced periodic flooding caused by seasonal snow melt of the White Mountains. Throughout what remains of Hill, here and there one can see different markings people have made to show the water level at various stages of flooding. The area is now known as the Franklin Falls Dam Recreational Area. The physical actions such as "curls" and "sleep" suggest a relaxed or suspended state and also further connotative semiotics which reinforce the idea of the poem as a memory. The "horned // pout sleep" because they have made their nest in the "green // mailbox" (lines 8-11). The plot of the poem fits the observations of the speaker in describing the submerged town. Here it is important to note that Hall acknowledges "the mystery which exists in the plot" (in: Turner 1977: 128). The images in the poem take on the dual nature of actual, once living or functional aspects of a community that no longer exists in the same sense as other living cultural entities. This dualistic nature of imagery has been exploited through the hermeneutic of the work and gives the poem a dreamlike quality of memory.

The next eight lines establish what I will call the imagined action of the poem as the connotation of language suggests further actions and images the reader would see if the town existed. Hall writes, "a boy walks // from a screened / porch beneath // the man-shaped / leaves of an oak // down the street looking / at the town" (lines 12-18). In this sense, the action takes precedent in these lines. In terms of the semantic code, the image of a boy walking from a screened porch in a town yard where an oak tree grows, is an iconic American image. The theme of normalcy and sheer dailiness come to mind. The boy's actions also shift the reader's perspective as he walks down the street making his own observations of the town. These lines illustrate semantic and symbolic codes conjoined as the image itself has been loaded with purely American, symbolic meaning. Its cultural-referential meaning exists along similar lines of thought, as the image evokes any normal day in any small town in America. The above seven lines comprise another hermeneutic code in that the entire action constitutes heightened realism-literally an imagined action or series of actions as the town no longer exists. Within these lines, "the man-shaped / leaves of an oak" 
connotate their literal symbolism of patriarchy (lines 15-16). The oak is positioned over the house and is associated with "man", the man being in this historical context, the provider, protector, family leader, strong, sheltering and so forth. The boy walks from the house, the symbolic center of family life. Setting subsumes the reading at the conclusion of the poem as the two semantic elements are unified through action.

In the last six lines, imaginative and actual merge again as the poem achieves closure with the focus remaining on the door the boy opened. He has left the house and is walking down the street "looking / at the town // of Hill that water / covered forty // years ago / and the screen // door shuts / under dream water" (lines 17-24). After the actional code of the boy looking at the town, the reader learns cultural-referential facts concerning the flooding of the town. "The Town of Hill" was published in 1975. Forty years before this, the government bought properties in the area between 1935 and 1938. Construction of the dam did not begin until the latter. Severe flooding prior to 1935 prompted intervention of the Army Corp of Engineers. Literally, the poem provides the final action of the plot: "water / covered forty // years ago / and the screen // door shuts / under dream water" (lines 19-24). Since the boy cannot literally "look" at the town, one hermeneutic yields a final one as the reader sees that the "door shuts / under dream water" (lines 23-24). The actional code here blends with the hermeneutic in that this door, like all images of the town in the poem, remain imaginary. Thus as well, the poem ends. Further, the semantic aspects of connotative language such as "down", "covered", "shuts", and "under" create the distance of memory and the present. It is almost as if the speaker places himself in the situation of the boy, walking literally through town, though recalling its past as well.

The actional and cultural-referential lines "the town // of Hill that water / covered forty // years ago" serve also as the antithesis of the literal/figural motif of the poem and ground the context back in the actual setting where the poem began. The last three lines however, reestablish the hermeneutic enigma of not knowing if the town is real or if the poem is just a memory as the reader is faced again with another submerged town image where "the screen // door shuts / under dream water" (lines 22-24). In another semantic and hermeneutic sense, the poet has chosen to repeat only a few words throughout the poem; “town", "Hill”, “water", "under”, and "screen”. This semantic cluster appears twice throughout the work, including the title. Usually, when a poet utilizes repetition, it is a sign that attention is being directed at some aspect of the given. The meaning of this cluster further connotates the factual content of the poem's subject. Only one word appears three times throughout: "water" (lines 3, 19 and 24). Contextually it is associated by its literal position adjacent to words such as "church", "Hill" and "dream" (lines 3, 19 and 24). Also of significance, each cluster appears in separate parts of the poem, once at the beginning and once at the end. The word "water" has been given as the last word in the last line. Connotatively, this cluster of words functions as an allusion to the actual facts of the cultural-referential event of the poem. Even though it is now a well-worn analogy, the speaker may feel as if the water exists as a great symbol of the unconscious or the memories that form this imagined landscape of a town that no longer exists. The last lines achieve closure in that the door the boy opens, is the door that 
closes. This door, literally of home, represents connotatively, the center of all meaning and personal history, the heart of one's existence. When this "door shuts / under dream water", the memory no longer exists (lines 23-24). Donald Hall has provided a well-crafted poem, which appears on the surface as a very simple memory poem, though in fact possesses many complex aspects.

Hall's use of rhythm and line-break in "The Town of Hill" blend semantic, hermeneutic and symbolic codes. The natural spoken rhythm of mainstream free-verse of 1975 has been deliberately confused and enjambed in the poet's use of line-break. Hall says that in the process of writing this poem he "became aware that" he "was writing a single sentence, and became interested in the" poem's "syntax" (in: Turner 1977: 130). Here, unusual aspects exist as intentional complications of structure which have a logical function in understanding the dynamic of the way the poem operates. Reading the lines as if they were natural speech patterns, they do not flow or seem to flow naturally to logical pauses visually on the page. In terms of image, the poem takes a very carefully paced, though couplet-like structure. Syntactical units have been broken up as units in and of themselves from the beginning of the poem to the end. Hall employs commas, though there exists only one end-stopped line, the very last.

Reading "The Town of Hill", even in the first two lines, flow of rhythm is disrupted. The comma pauses before the word under, and the word would normally have position as the first word in the next syntactical unit if read as a flow reflective of natural speech rhythms. Clearly then, it is not because other things are happening. That kind of rhythm, whatever you choose to call it, has been disrupted. To further complicate rhythm, Hall has structured the shortened lines into stanzas. How is the reader to think of the white space between? In one sense, we begin to see after a few stanzas where the natural rhythms are and looking at the arrangement on the page, the mind sees this connected flow, though the reading utterly counters that unity. Here, material and the local contribute to the meaning of structure. Discord exists because the town of Hill was forever abandoned and submerged in water. In reading, the mind wants to place certain units together that have literally been separated on the page. During the reading process, one wants to place "under" at the beginning of the second line so that it reads with the natural rhythm of statement, like a sentence: "Back of the dam / under a flat pad" (lines 1-2). These are coherent ideas, separate though unified thoughts describing this underwater town. Although the reader does not sense this yet, the speaker describes the surface and only in reading the lines that follow do we then get the sense that something different is forming from other sensibilities.

This disruption of syntax creates a harmony of the dualities which remain central to the poem's structure. This type of structural complexity however, was not the original intention of the author. Hall says in writing the poem, "the various orders were not thought out ahead of time, but improvised, looked at, rejected and tried again", though not to "a conclusive ending intellectually" as "the poem began to make this spacey, skinny thing" (Turner 1977: 131). The imagistic expectations of images have been utilized as an enigma within the line structure conveying a sense of prolonged attention to image and the nature of memory. Every other line contains an image of submersion. Though these parts of the town environment no longer exist, the reader eventually senses 
through additional readings what has taken place. The speaker says, "down the street looking / at the town // of Hill that water / covered forty // years ago" (lines 17-21). Attention shifts back and forth among two types of imagery - between what was once real and the reality of submersion. A real place has been characterized through images of every-day life and a flooded landscape which further recapitulates the tension or conflict of past and present. The speaker associates the submerged imagery of the town with dream conveying that memories of the actual may be just as elusive. This idea concludes the poem, figuratively and literally. As we read, "and the screen // door shuts / under dream water" (lines 22-24). Symbolically, the physical landscape as well as the remembered past only exist in the remote obscurity of memory like objects under water.

\section{Conclusion}

My conclusion concerning the structure of "The Town of Hill" involves a summary of the features of the poem as a sentence. This may prove helpful in understanding its enjambment as well as its hermeneutic enigmas. Although the poem appears to be constructed in sets of two lined stanzas, the structure of a single sentence underlies the whole. As a sentence, the subject, "the town // of Hill that water / covered forty // years ago" has been placed at the end of the sentence (lines 18-21). The poem begins with the setting of the dam, though adverbially, "Back of the dam", and specifically, the preposition "under" denotes both the submerged town and the speaker's placement in the present, thinking back on the history of the town (line 1). Within the apposition of the sentence have been provided four groups of images that describe the fact of submersion through common objects from every-day life. Here, unconventional use of enjambment creates an unnatural pause in the lines and this primarily serves the hermeneutic of blurring the distinction between past and present. This type of line structure exists throughout the poem. The images illustrate visually what is submerged, though also as in memory, what once existed as a normal town. These images are as follows; "church / bells ring // in the ears of lilies", the second of "a child's swing // which curls in the current / of a yard...," here blending with the third, where "horned // pout sleep / in a green // mailbox..." and here again blending as if in a hermeneutic of the line-break with the fourth motif, "... and / a boy walks // from a screened / porch beneath // the man-shaped leaves of an oak // down the street looking / at the town" (lines 3-18). At this point, the reader sees these images as if with the speaker, thinking back or even peering under water ourselves at the remains. I said earlier that the subject of this sentence has been displaced, moved to the end of Hall's sentence, something writers of prose often do to add emphasis to a thesis statement or when they try to draw attention to an idea. Here, the lines containing the subject function as a hermeneutic of the line in that this information dispels the enigma of all images which have come before in the series. This signals the epiphany, mild though it is, which clarifies all images between the setting in lines one through two as remaining part of the speaker's remembered landscape. After this point of clarity in the poem, the fourth image continues: "and the screen // door shuts / under dream water" (lines 22-24). This fourth image remains most important in terms of structure for it contains the locus of conflict of the entire sentence. The speaker says, “... and / a boy walks // from a screened / porch beneath // the 
man-shaped / leaves of an oak // down the street looking / at the town" (lines 1-18). The boy has no name and in this way becomes allied with the speaker, as if thinking back, trying to recall what the reader sees happening in the poem. The boy "walks from" the house, the center of family life, "from", more specifically those "man-shaped / leaves of an oak", the father symbol, though only to engage in the detached activity of "looking at the town" (lines 12-18). Since the fourth image has been disrupted by the more factual subject of the poem, also centrally denoted in the poem's title, the central conflict remains one of memory. The apposition of the factual statement refers to the literal condition of water covering the town, though it places emphasis on the historical aspect, the fact that much time has passed and that this happened four decades ago from the imagined present of the speaker; only however, if one imagined the "present" of any work to be the year of first publication. This is established by the literal, cultural-referential facts of the history of the town of Hill. Thus, the poem creates a distance both within itself and between material and time.

Although one could interpret the symbolic import of "The Town of Hill" as a memory poem, I would not contribute to such a reading an atypical psychological structure of the whole. One could easily say the town's being submerged represents human consciousness, or the unconscious due to their holding the power of memory, in fact, images which constitute memory. The poem carries symbolism of communal loss and patriarchy, through the hermeneutic codes it creates the distance and murkiness of memory. Evidence is lacking in the poem to argue that the conflict exists between father and son. Even arguments for the poem as some rite of passage yield no moment where this is ever confirmed in the actual code or any other aspect of the poem. I would not entirely argue much importance in the fact that the structure is, technically, a sentence because the structure remains visually and verbally poetic. Since we cannot examine the poem in sentence form in the same way we diagram sentences in the study of grammar, the more rewarding examination in this respect lies in the poem as a poem. Perhaps the most important parallel remains among the boy and the speaker, with no explicit conflict other than the fact of loss and the passage of time. Recall also, however, man's engineering, one type of industrial science which creates structures and deploys them, is what creates the loss, though saves life and townships in turn. I would therefore, place the most meaningful emphasis on the poet's role of creation, especially because of the facts we know about Hall's poetic process in writing this poem. Hall says that he was interested in the idea of the single sentence as a poem, though he said he tested the combinations of line structure, kept re-arranging them throughout the poem's development. Regarding lineation, Hall writes that he conceived of the line structure in such a way that "Alternative lineations are possible..." though also with “...the sound as reinforcing sense, or enforcing sense for the first time..." (in: Turner 1977: 130). This explains the poem's odd enjambment. He further says, "I kept changing the organization of things...Certainly the various orders were not thought out ahead of time but improvised..." (in: Turner 1977: 131). This signals pleasure in the play of words and language in the conscious mind of the creator. As Barthes says in "From Work to Text", "The Text...decants the work...from its consumption and recuperates it as play, task, production, 
practice" (Barthes 1989: 62). I find this notion of play central to the structure employed in "The Town of Hill", though it also has a central role in Hall's poetic process.

\section{References}

Barthes, R. 1972. Critical Essays. Translated by Richard Howard. Evanston: Northwestern University Press.

Barthes, R. 1975. S/Z: An Essay. Translated by Richard Miller. Preface by Richard Howard. New York: Farrar Straus \& Giroux.

Barthes, R. 1989. The Rustle of Language. Translated by Richard Howard. Berkeley: University of California.

Culler, J. 1976. Structuralist poetics: Structuralism, linguistics and the study of literature. Journal of Aesthetics and Art Criticism 34 (3): 352-353.

Culler, J. 1983. Roland Barthes. Oxford: Oxford University Press.

Dirgasari, B. 2008. A symbolism analysis as reflected in John Keats's “Ode to a Nightingale." Thesis, UIN, Jakarta.

Frye, N. 1963. Fables of Identity. New York: Harcourt, Brace \& World.

Hall, D. 1974. The Town of Hill. Boston: Godine.

Hall, D. 1978. Goatfoot, Milktongue, Twinbird: The psychic origins of poetic form. In: D. Hall (ed.), Claims for Poetry, 141-150. Ann Harbor: The University of Michigan Press.

Felluga, D. (n.d.). Modules on Barthes: On plotting. Introductory Guide to Critical Theory, 26 June. 2017, www.cla.purdue.edu/english/theory/narratology/modules/bar thescodes.mtml.

Finch, A. 2012. Villanelles. New York: Alfred A. Knopf.

Fuller, J. 1972. The Sonnet. London: Methuen.

Jakobson, R. \& Levi-Strauss, C. 1962. Les Chats de Charles Baudelaire. L’Homme 2: 5-21.

Kane, J. 2012. Introduction: The history of the Villanelle. In: A. Finch \& M.-E. Mali (eds.), Villanelles, 19-24. New York: Alfred A. Knopf.

Keats, J. 1816. On first looking into Chapman's Homer. www. poetryfoundation.org. (September 2019).

Leitch, V. B. 1988. American Literary Criticism from the 1930s to the 1980s. New York: Columbia University Press.

Nims, J. F. 1985. A Local Habitation: Essays on Poetry. Ann Arbor: The University of Michigan Press.

Perloff, M. 2004. Differentials: Poetry, Poetics, Pedagogy. Tuscaloosa: University of Alabama Press.

Reniminryu, M. A. 2009. Analysis on Roland Barthes' Codes in the Wizard of Oz: A Semiotic Approach. Undergraduate Thesis, English Department, Gundarma University.

Riffaterre, M. 1970. Describing poetic structures: Two approaches to Baudelaires's “Les Chats”. In: J. Ehrmann (ed.), Structuralism, 188-230. Garden City, NY: Doubleday.

Scholes, R. 1974. Structuralism in Literature: An Introduction. New Haven/London: Yale University Press. 
Turner, A. (ed.). 1977. Fifty Contemporary Poets: The Creative Process (Donald Hall). New York: David McKay.

Zaib, S. \& Mashori, G. M. 2014. Five codes of Roland Barthes in Shahraz's story, "A Pair of Jeans": a Post-structural analysis. ELF Annual Research Journal 1: 171-184.

\section{$* * *$}

John Timothy Robinson is a mainstream poet of the expressive image and inwardness from the Kanawha Valley in Mason County, West Virginia. His poetics was developed in the tradition of James Wright, Rita Dove, Donald Hall, Marvin Bell, Maxine Kumin, WS Merwin and Robert Bly among many others. John's 150 works have appeared in 102 journals throughout the United States, Canada, the United Kingdom and India. He is also a published printmaker with eighty-eight art images and photographs appearing in journals, electronic and print in the United States, Italy and Ireland. 